\title{
Strategi Peningkatan Kinerja Perusahaan Berdasarkan Keunggulan Kompetitif yang Berkelanjutan dan Perencanaan Sumber Daya
}

\section{Strategy to Increase Company Performance Based on Sustainable Competative Advance (SCA) and Enterprice Resource Planning (ERP)}

\author{
Dase Purnama $^{1}$, Budi Purwanto ${ }^{1 *}$, Abdul Kohar Irwanto ${ }^{1}$ \\ ${ }^{1}$ Departemen Manajemen, Fakultas Ekonomi dan Manajemen, IPB Kampus Dramaga Bogor 16680
}

\begin{abstract}
Optimization of resources can be achieved by using technology to improve operating performance in order to support the company's business activities. This study was conducted in the implementation of Enterprise Resource Planning (ERP) system in plantation company conducted by PT Kencana Group in 16 subsidiaries, five subsidiaries have implemented ERP as an effort of transformation in using information system. Information and Technology can provide a competitive advantage for the company by adding value to various aspects such as increased operational performance and cost reduction. The research aims to identify the utilization of the company's ERP, ERP implementation measure performance, identify factors that affect the performance of the company, as well as measuring the impact of ERP on business performance. Methods of data analysis used in this research is descriptive and qualitative analyzes to provide a general overview of the study. Inter-variable relationship analysis was done by structural equation modeling (SEM) with partial least square approach using SmartPLS software. Hypothesis test is done by regression analysis to measure the validity and significance of influence of each veriabel, and to estimate the direction and magnitude of its influence respectively. The results showed that there is a significant influence of performance factors of ERP utilization that can affect company performance. Operating performance increased by $1 \%$ would increase the net profit margin amounted to 38.7\%. Furthermore, enterprise resource planning and sustainable competitive advantage have a positive effect on company performance with general and environmental cost factor significantly less than 0.05. The impact of ERP on the performance of the company has decreased the cost of general expenses. While the impact of SCA on the company's perceived performance at this time is that the environment such as the acreage still has not reached the hectare per staple, and the standard number of labor has not been in accordance with the normative of the garden area.
\end{abstract}

Keywords: company performance, Enterprice Resource Planning (ERP), Sustainable Competitive Advantage (SCA), Structural Equation Modelling (SEM), regression.

\begin{abstract}
ABSTRAK
Optimalisasi sumber daya dapat dicapai dengan menggunakan teknologi untuk meningkatkan kinerja operasi dalam rangka menunjang kegiatan bisnis perusahaan. Dalam penerapan sistem Enterprise Resource Planning (ERP) di perusahaan perkebunan, Studi kasus dilakukan pada PT Kencana Group yang terdiri atas 16 anak perusahaan, lima anak perusahaan sudah menerapkan ERP sebagai suatu upaya transformasi menggunakan sistem informasi yang handal. Informasi dan Teknologi dapat memberikan keunggulan kompetitive bagi perusahaan dengan memberikan nilai tambah terhadap berbagai aspek seperti peningkatan kinerja operasional dan pengurangan biaya. Penelitian bertujuan mengidentifikasi utilisasi ERP pada perusahaan, mengukur kinerja implementasi ERP, mengidentifikasi faktor-faktor kinerja utilisasi ERP, ERP dan SCA yang mempengaruhi kinerja perusahaan, mengukur dampak penerapan ERP terhadap kinerja perusahaan. Metode analisis data yang digunakan dalam penelitian ini adalah analisis deskriptif dan analisis kuantitatif yang dilakukan untuk memberikan gambaran mengenai variabel penelitian. Kemudian dilakukan pengujian pengaruh antar variable penelitian dengan model analisis Structural Equation Modelling (SEM) dengan pendekatan partial least square menggunakan software SmartPLS dan analisis regresi juga dilakukan untuk meramalkan bagaimana keadaan (naik turunnya) variabel dependen, bila dua atau lebih variabel independen sebagai faktor prediktor dimanipulasi atau dinaik turunkan nilainya. Hasil menunjukkan adanya pengaruh signifikan dari faktor-faktor kinerja utilisasi ERP yang dapat mempengaruhi kinerja perusahaan dari hasil perhitungan SEM (hipotesis 1) diukur dengan kinerja operasional yang meningkat maka akan meningkatkan Net Profit Margin pada taraf $1 \%$ dengan nilai 0,387 . Sedangkan dari hasil perhitungan regresi bahwa enterprise resource planning dan sustainable competitive advantage berpengaruh terhadap kinerja perusahaan dengan faktor biaya beban umum dan planet memiliki nilai signifikan kurang dari 0,05. Dampak ERP terhadap kinerja perusahaan yang dilihat oleh perusahaan ini terjadi penurunan biaya beban umum seperti paperless. Sementara dampak SCA terhadap kinerja
\end{abstract}


perusahaan yang dilihat kondisi perusahaan saat ini adalah Planet seperti luasan areal masih belum mencapai satuan hektar per pokok dan People seperti standar jumlah tenaga kerja belum sesuai dengan normatif luasan kebun.

Kata Kunci: kinerja perusahaan, perencanaan sumber daya, keunggulan kompetitif yang berkelanjutan, SEM.

*Corresponding author

Alamat e-mail: budipurwanto@apps.ipb.ac.id

\section{PENDAHULUAN}

Optimalisasi sumber daya dapat dicapai dengan menggunakan teknologi untuk meningkatkan kinerja operasi dalam rangka menunjang kegiatan bisnis perusahaan. Dalam penerapan sistem Enterprise Resource Planning (ERP) di perusahaan perkebunan (studi kasus PT Kencana Group) yang terdiri dari 16 anak perusahaan diantaranya lima anak perusahaan sudah menerapkan ERP merupakan agenda utama perusahaan sebagai suatu upaya transformasi ke semua anak perusahaannya untuk menjadi lebih baik khususnya dalam penyediaan sistem informasi yang handal. Hal ini merupakan salah satu inisiatif besar yang dilakukan oleh perusahaan. Umumnya, perusahaan yang memilih investasi teknologi menginginkan terciptanya competitive advantage sehingga dapat meningkatkan kinerja perusahaan (Ruivo 2014). Salah satu strategi perusahaan yang dapat digunakan untuk memenangkan persaingan dengan memunculkan Sustainable Competitive Advantage (SCA). Informasi dan Teknologi dapat memberikan competitive advantage bagi perusahaan dengan memberikan nilai tambah terhadap berbagai aspek seperti value chain, peningkatan kinerja operasional, pengurangan biaya, dan peningkatan kualitas pengambilan keputusan. Perusahaan memiliki risiko kehilangan competitive advantage dengan proses pencatatan yang dilakukan ERP. Sistem Perusahaan merupakan pilihan investasi teknologi yang penting untuk manajer operasi. ERP merupakan salah satu enterprise sistems yang telah berhasil diimplementasikan oleh banyak perusahaan di dunia.

Terdapat beberapa alasan yang membuat ERP dibutuhkan didalam perusahaan yaitu ERP dapat memberikan informasi secara akurat dan waktu sebenarnya kepada bagian yang membutuhkan (Hsu 2013). Selain itu, sistem ERP dapat meningkatkan nilai pasar dan kinerja perusahaan yang dilihat dari efisiensi dan efektivitas sebuah proses dengan mempertimbangkan waktu dan biaya (Hunton 2003). Modul-modul ERP telah didesain sedemikian rupa untuk merefleksikan operasional sekumpulan proses bisnis dengan cara-cara yang khusus dan terbaik (Best Practices). Sejak mulai dikenal dan di Eropa berbagai sistem ERP beredar di pasaran, sistem ERP yang komersial antara lain System Application and Product in Data Processing (SAP), Baan, Oracle, IFS, Peoplesoft dan J.D. Edwards, sedangkan sistem ERP open source yang popular sekarang ini adalah Compiere, Adempiere, WebErp. Perusahaan besar di Indonesia banyak yang telah mengimplementasikan ERP-SAP, misalnya Astra International, Toyota Astra Motor, Bentoel Prima, United Tractor, Pertamina, Telkomsel, Auto 2000, Blue Bird dan beberapa perusahaan lain. Modul yang diimplementasikan tiap perusahaan pun beragam. Ada yang hanya memakai untuk keperluan area tertentu seperti Financial Accounting saja atau Sales and Distributon saja, namun banyak pula yang mengintegrasikan beberapa modul.

Masalah bisnis yang sebenarnya disebabkan oleh data yang dikelola dengan kurang tepat, keberhasilan bisnis dimungkinkan oleh pengelolaan data atau tindakan manajemen data yang memiliki perbedaan (Goodhue et al. 1988). Melalui sistem ERP ini, maka perusahaan memiliki kemampuan untuk mengintegrasikan seluruh proses dan data perusahaan sehingga mampu menjadi sumber kebenaran tunggal untuk data operasi perusahaan. Hal ini diharapkan mampu 
meningkatkan kecepatan proses bisnis internal perusahaan. Sistem ini menjadi backbone utama pendukung seluruh proses bisnis perusahaan, diantaranya untuk mengoperasikan sistem informasi bagi sales process, procurement process, material management, payroll system, financial reporting, dan lainnya. Keuntungan aplikasi ERP ini diantaranya adalah menghilangkan duplikasi input data, mengurangi kebutuhan tenaga kerja, serta dapat menyediakan informasi yang berkualitas untuk pengambilan keputusan perusahaan, sehingga harapannya adalah terjadi konsistensi dan akurasi data dapat lebih diandalkan.

Perusahaan telah menggunakan sistem ERP sejak tahun 2015, namun hingga tahun 2017 aplikasi tersebut belum dimanfaatkan secara optimal karena perusahaan belum mendapatkan output yang signifkan dan menghasilkan data yang akurat bagi perusahaan. Hal ini dapat terlihat dari laporan kinerja perusahaan yang belum terintegrasi. Apabila dikelompokan, maka terdapat beberapa penyebab penggunaan ERP yang tidak maksimal antara lain keterbatasan keterampilan dan kompetensi sumber daya manusia, ketidakseragaman proses bisnis, kurangnya aktivitas change management serta kelemahan sistem kendali maupun monitoring atas proses transaksi yang berlangsung.

Perusahaan telah menggunakan sistem ERP sejak tahun 2015, namun hingga tahun 2017 aplikasi tersebut belum dimanfaatkan secara optimal karena perusahaan belum mendapatkan output yang signifkan dan menghasilkan data yang akurat bagi perusahaan. Hal ini dapat terlihat dari laporan kinerja perusahaan yang belum terintegrasi. Apabila dikelompokan, maka terdapat beberapa penyebab penggunaan ERP yang tidak maksimal antara lain keterbatasan keterampilan dan kompetensi sumber daya manusia, ketidakseragaman proses bisnis, kurangnya aktivitas change management serta kelemahan sistem kendali maupun monitoring atas proses transaksi yang berlangsung.

Konsep SCA yang dikenal dengan sebutan Triple Bottom Lines (Profit, Planet and People). Konsep ini dianggap sebagai dasar dalam membangun bisnis yang keberlanjutan (Elkington 1998). Perusahaan perlu peduli terhadap lingkungan alam sekitar, hak-hak pekerja, pemerintah, dan pengaruh perilaku bisnis terhadap isu-isu sosial pada umumnya seperti masalah kekurangan pangan, kemiskinan, pendidikan, perawatan kesehatan yang semuanya dihubungkan dengan profit.

Berdasarkan realitas tersebut, dilakukan evaluasi dan analisis yang hasilnya adalah langkah penyempurnaan terhadap operating model pemanfaatan ERP yang sudah dimiliki agar memberi nilai tambah signifikan kepada perusahaan. Implementasi Information System (IS) di perusahaan ini bukan sekedar pada level support operational akan tetapi meningkat pada level decision making system. Penerapan diharapkan mampu memberikan informasi yang berkualitas untuk mendukung proses pengambilan keputusan bagi manajemen.

Keberadaan sistem informasi ini menjadi sangat vital bagi suatu perusahaan, oleh karenanya setelah implementasi sistem ERP dilakukan, maka diperlukan upaya maksimal agar sistem ERP ini dapat digunakan dan dapat dipertahankan sustainability-nya sehingga benarbenar memberikan manfaat bagi perusahaan. Untuk menjaga keberlanjutan (sustainability) dari implementasi ini maka pemegang saham meminta kepada Direksi untuk mengelola sistem informasi di perusahaan sebagai modal untuk menciptakan nilai bagi perusahaan yang dituangkan dalam kontrak manajemen.

Penelitian ini dilakukan pada perusahaan yang telah mengimplementasikan ERP secara nasional. Berdasarkan observasi awal ditemukan banyak faktor yang menyebabkan implementasi ERP belum signifikan dirasakan oleh korporasi. Kontrol manajemen menjadi salah satu isu strategis, karena implementasi ERP belum memberikan manfaat yang signifikan salah satu masalah adalah tidak ada ukuran kinerja yang dapat dijadikan dasar bagi manajemen untuk memastikan bahwa implementasi ERP sudah sesuai harapan. Sementara itu tingkat manfaat ERP dipengaruhi oleh faktor-faktor kegunaan (utilisasi) sistem itu sendiri. Penelitian bertujuan mengidentifikasi utilisasi ERP perusahaan, mengukur kinerja implementasi ERP, mengidentifikasi faktor-faktor kinerja utilisasi ERP, ERP dan SCA yang mempengaruhi kinerja perusahaan, mengukur dampak kinerja utilisasi ERP, ERP dan SCA terhadap kinerja perusahaan. Metode analisis data yang digunakan dalam penelitian ini adalah analisis deskriptif 
dan analisis kuantitatif yang dilakukan untuk memberikan gambaran mengenai variable penelitian. Kemudian dilakukan pengujian pengaruh antar variable penelitian dengan model analisis Structural Equation Modelling (SEM) dengan pendekatan partial least square menggunakan software SmartPLS (Ghozali 2008).

Penelitian terdahulu pada penelitian ini diantaranya yaitu proses perencanaan yang tepat untuk menggunakan produk terbaik sangat bergantung pada tujuan bisnis dan organisasi (Goodhue et al. 1988). Bagaimana arsitektur sistem informasi dapat digunakan untuk mendukung organisasi pada 1990-an. Penelitian ini membahas dua solusi arsitektur untuk masalah ini: "jalan yang tinggi dan rendah jalan" dan "manfaat dan perangkap masing-masing" (Allen and Boynton 1991). Teknologi salah satu komponen dari investasi IT biasanya ada pengeluaran besar pada pelatihan, proses desain ulang dan perubahan organisasi lain yang menyertainya investasi system (Brynjolfsson and Hitt 1998). Teknologi informasi dan berkelanjutan keunggulan kompetiti sebuah analisis berbasis sumberdaya. Analisis ini menunjukkan bahwa menggunakan IT untuk mendapatkan keuntungan kompetitif yang berkelanjutan tidak mungkin mudah (Mata et al. 1995). Konsep keunggulan kompetitif dan pengalaman yang diperoleh dari inovasi yang sukses untuk menghasilkan klasifikasi dan kerangka kerja untuk memandu mencari peluang. Hasil yang didapatkan dari penelitian ini diakhiri dengan daftar pertanyaan penting bagi manajemen puncak untuk mempertimbangkan sebelum memulai pembangunan IOS (Johnston and Vitale 1988). Strategic Information System Planning Success: suatu investigasi dari membangun dan pengukurannya, hasil penelitian digunakan sebagai alat untuk patokan upaya perencanaan serta sebagai dasar untuk operasionalisasi variabel terkait kunci dalam penelitian SISP (Segars and Grover 1998).

Pengaruh penyelarasan strategis tentang penggunaan sumber daya berbasis is untuk keunggulan kompetitif, penelitian ini sangat mendukung pandangan umum yang efektif ISP-BP keselarasan presages penggunaan sumber daya IS berdasarkan untuk keunggulan kompetitif. Namun, itu tidak begitu kuat suport asosiasi analog dari BP-ISP keselarasan dengan keunggulan tersebut. Sebuah pemahaman yang lebih dalam temuan ini akan mengungkapkan bagaimana organisasi dapat menerapkan keselarasan strategis untuk IS sumber daya berbasis untuk mendapatkan keunggulan kompetitif dan meningkatkan kinerja organisasi (Kearns dan Lederer 2000). Perencanaan sumber daya perusahaan dalam bisnis rekayasa ulang, usaha pasti mencapai praktik bisnis terbaik dengan menerapkan ERP, dalam upaya untuk memposisikan kesuksesan di abad kedua puluh satu (Siriginidi 2000). ERP dan integreasi aplikasi, hasil penelitian mengkonfirmasi AI sebagai sarana baru integrasi sistem yang memberikan nilai tambah dengan menempatkan logika bisnis dalam jaringan aplikasi, sehingga menciptakan infrastruktur sistem informasi yang lebih dinamis (Themistocleous et al. 2001). ERP dan pemeliharaan terbaik: analisis komparatif, makalah ini menggambarkan perbedaan dalam kompleksitas pelaksanaan, tingkat fungsi, proses bisnis potensial keselarasan dan pemeliharaan yang terkait (Light et al. 2001). Masalah implementasi erp di negara-negara maju dan berkembang (Huang and Pavia 2001). Proses seleksi ERP pada organisasi-organisasi menengah dan besar, dalam makalah ini, perbedaan antara organisasi berukuran kecil, menengah, dan besar mengenai persyaratan sistem ERP dan proses seleksi yang dieksplorasi berdasarkan studi empiris. Misalnya, pendekatan yang berbeda untuk kepegawaian kelompok menunjukkan proses seleksi yang ditemukan, sebagai bentuk pengambilan keputusan yang lebih terpusat di organisasi atau departemen IT dengan lebih sedikit orang yang terlibat di tempat pada organisasi yang lebih kecil. Selain itu, keputusan dalam kelompok organisasi yang lebih kecil berdasarkan model yang kompleks kurang dan metode yang lebih murah dari pengumpulan informasi (Bernroider and Koch 2001).

Makalah ini telah meneliti potensi penggunaan sistem ERP dalam luasan model kurikulum IS seperti IS'97, memberikan panduan untuk mereka yang mungkin mempertimbangkan penggunaan ERP dalam kurikulum mereka (Hawking et al. 2001). Faktor penting untuk keberhasilan pelaksanaan sistem perusahaan, menurut tinjauan berbagai literatur terdapat sebanyak 11 faktor penentu keberhasilan implementasi ERP. Jurnal ini telah berhasil mengidentifikasi semua faktor penting tersebut. Penelitian ini akan dikembangkan dengan mengirimkan kuesioner survei kepada perusahaan untuk menilai tingkat kekritisan dan

Jurnal Manajemen dan Organisasi (JMO),

Vol. 9, No. 1, April 2018, Hal. 22-34 
pentingnya keberhasilan faktor yang diidentifikasi dalam literatur ERP (Fui et al. 2001). Mengintegrasikan proses bisnis untuk penjajaran global dan manajemen rantai pasok, Sementara terdapat sedikit bukti penelitian mengenai integrasi proses memperluas seluruh rantai pasokan, beberapa efisiensi global rantai pasokan atau organisasi virtual. Dari hasil studi kasus, dapat dilihat pentingnya komunikasi antara proses dan antara mitra dalam rantai pasokan. Bisnis yang mendapatkan keunggulan kompetitif dengan memaksimalkan (McAdam and McCormack 2001). Strategi manajemen perubahan untuk implementasi ERP yang sukses, implementasi ERP yang sukses membutuhkan pencocokan strategi yang tepat dengan tahap yang sesuai untuk mengatasi sumber resistensi (kebiasaan dan risiko yang dirasakan) secara efektif (Aladwani 2001). Kontrol dan koordinasi dalam konfigurasi ERP global, Ssstem ERP menjadi elemen penting dari strategi kerangka dan informasi arsitektur MNC (Clemmons and Simon 2001).

\section{METODE PENELITIAN}

Penelitian ini dilakukan dengan pendekatan studi kasus pada PT Kencana Group berkantor pusat berlokasi di Jakarta Barat yang memiliki 16 anak perusahaan diberbagai daerah yaitu Bangka, Belitung, Kalimantan Timur, Kalimantan Selatan, Kalimantan Utara, Sulawesi Tengah dan Sulawesi Utara, dimana lima perusahaan sudah menerapkan ERP yang menjadi objek penelitian ini yaitu: PT Sawindo Kencana, PT Alamraya Kencana Mas, PT Agro Inti Kencanamas, PT Sawit Alam Permai dan PT Sawit Kaltim Lestari.

Data yang digunakan dalam penelitian ini data sekunder berasal dari laporan keuangan perusahaan pada tahun 2012-2017 yang diperoleh dari perusahaan. Menurut Sujarweni (2014) data sekunder adalah data yang didapat dari catatan, buku, majalah berupa laporan keuangan publikasi perusahaan, laporan pemerintah, artikel, buku-buku sebagai teori, majalah, dan lain sebagainya. Data yang diperoleh dari data sekunder ini tidak perlu diolah lagi. Sumber yang tidak langsung memberikan data pada pengumpul data. Data yang dikumpulkan oleh penulis adalah dalam bentuk laporan keuangan yang telah diaudit oleh auditor independen.

Metode pada penelitian ini menggunakan penelitian kuantitatif dengan jenis penelitian deskriptif kuantitatif. Menurut Umar (2013) metode deskriptif adalah metode yang bertujuan menguraikan sifat atau karakteristik dari suatu fenomena tertentu. Tujuan dari desain ini hanya mengumpulkan fakta dan menguraikannya secara menyeluruh dan teliti sesuai dengan persoalan yang akan dipecahkan. Perencanaan sangat dibutuhkan agar uraiannya dapat mencakup seluruh persoalan dan informasi yang dibutuhkan dapat dihasilkan. Data yang deskriptif biasanya langsung digunakan sebagai dasar untuk membuat keputusan-keputusan. Sedangkan menurut Sujarweni (2014) penelitian kuantitatif adalah jenis penelitian yang menghasilkan penemuanpenemuan yang dapat dicapai dengan menggunakan prosedur-prosedur statistik atau cara-cara lain dari kuantifikasi (pengukuran). Pendekatan kuantitatif memusatkan perhatian pada gejalagejala yang mempunyai karakteristik tertentu di dalam kehidupan manusia yang dinamakannya sebagai variabel. Dalam pendekatan kuantitatif hakekat hubungan diantara variabel-variabel dianalisis dengan menggunakan teori yang obyektif. Dalam upaya menjawab permasalahan yang ada, maka data yang dibutuhkan sebagai input untuk dianalisis adalah berupa data kuantitatif, mengingat dari serangkaian observasi/pengukuran hasilnya dapat dinyatakan dalam bentuk angka.

Penelitian ini terdiri atas variabel laten eksogen, yaitu kinerja utilisasi ERP, dan variabel laten endogen yaitu sustainable competitive advantage, enterprise resource planning dan kinerja perusahaan. Gambar 1 adalah path diagram yang merupakan model awal untuk mendeskripsikan suatu hubungan antara variabel laten eksogen dengan endogen. 


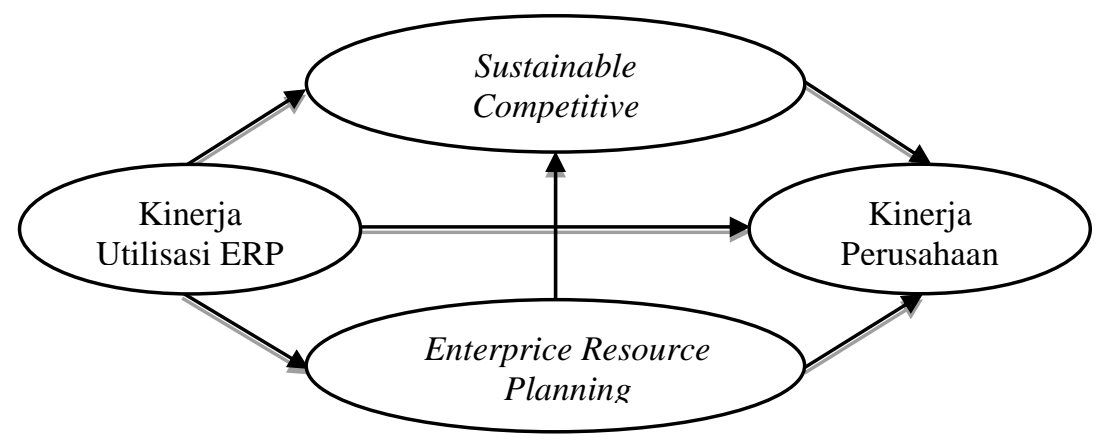

Gambar 1. Path Diagram pengaruh Kinerja Utilisasi ERP, Sustainable Competitive Advantage dan Enterprice Resource Planning terhadap Kinerja Perusahaan

Hipotesis pada penelitian ini adalah sebagai berikut:

H1: Kinerja utilisasi ERP berpengaruh positif terhadap kinerja perusahaan.

$\mathrm{H} 2$ : Kinerja utilisasi ERP berpengaruh positif terhadap sustainable competitive advantage.

H3: Kinerja utilisasi ERP berpengaruh positif terhadap enterprice resource planning.

$\mathrm{H} 4$ : Sustainable competitive advantage berpengaruh positif terhadap kinerja perusahaan.

H5: Enterprice resource planning berpengaruh positif terhadap kinerja perusahaan.

H6: Enterprice resource planning berpengaruh positif terhadap sustainable competitive advantage.

\section{HASIL DAN PEMBAHASAN}

\section{Kinerja Utilisasi ERP}

Berdasarkan hasil analisis dan pengolahan data kinerja utilisasi pada Grafik 1 Kinerja Operasional perusahaan mengalami fluktuasi, pada periode tahun 2012-2014 mengalami peningkatan, periode tahun 2014-2016 mengalami penurunan, pada tahun 2016-2017 kembali terjadi peningkatan, titik tertinggi pada tahun 2014 dan titik terendah pada tahun 2016.

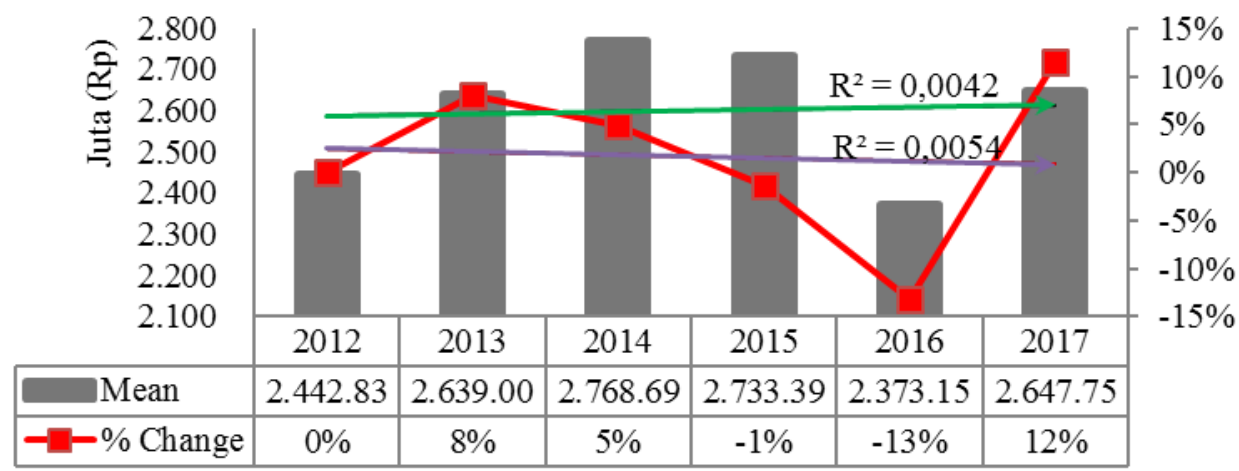

Grafik 1. Kinerja Operasional periode 2012 - 2017 Sumber: data diolah

Pada Grafik 2 dan Grafik 3 Efesiensi Waktu dan Efektifitas Waktu mengalami trend penurunan Efesiensi Biaya dan Efektifitas Biaya mengalami fluktuasi dari tahun 2012-2017, titik tertinggi pada tahun 2017. Kesimpulan kinerja utilisasi ERP yang dirasakan perusahaan adalah Efesiensi Waktu dan Efektifitas Waktu. 


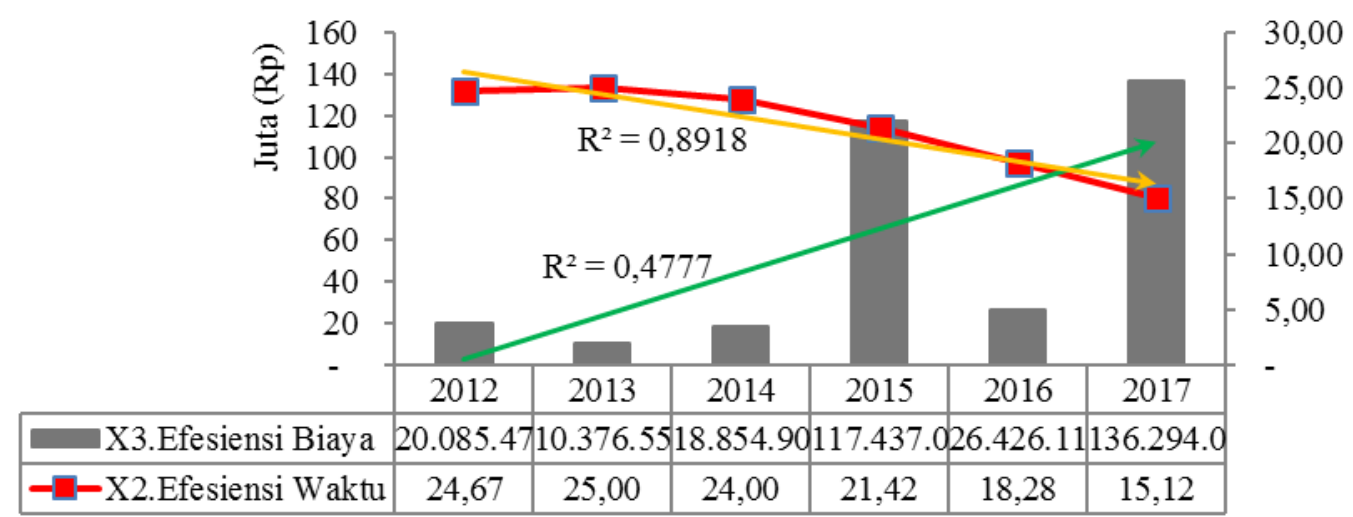

Grafik 2. Efesien Waktu dan Efesien Biaya periode 2012 - 2017

Sumber: data diolah

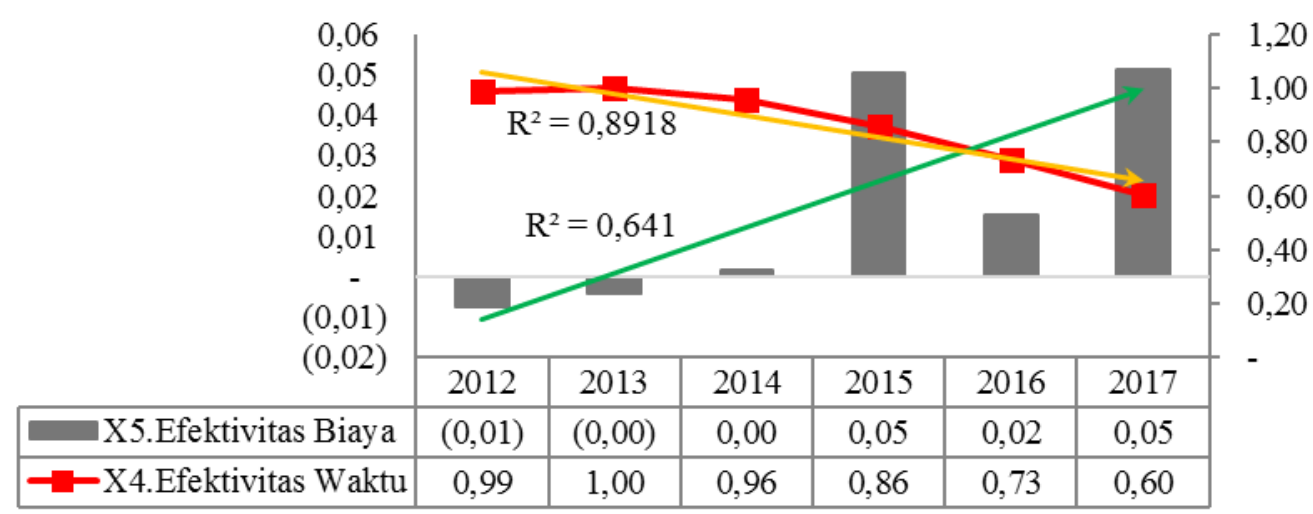

Grafik 3. Efektivitas Waktu dan Efektivitas Biaya periode 2012 - 2017

Sumber: data diolah

Jurnal Manajemen dan Organisasi

(JMO),

Vol. 9, No. 1, April 2018, Hal. 22-34

\section{Kinerja Implementasi ERP}

Penurunan Inventori perusahaan dan Peningkatan Penjualan terjadi pada tahun 2017 semenjak ERP diimplementasikan oleh lima perusahaan (Grafik 4 dan 5).

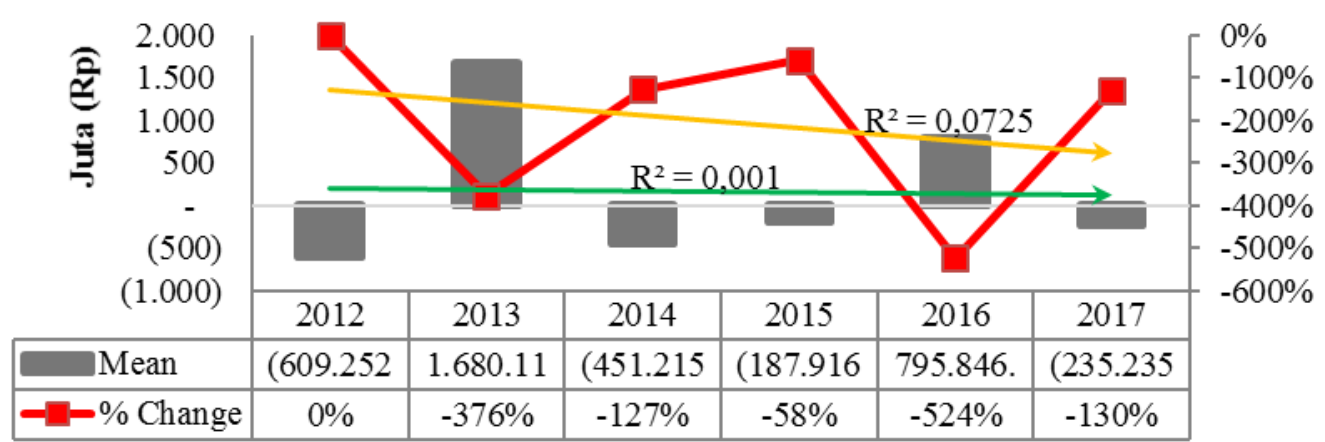

Grafik 4. Inventori periode $2012-2017$

Sumber: data diolah 


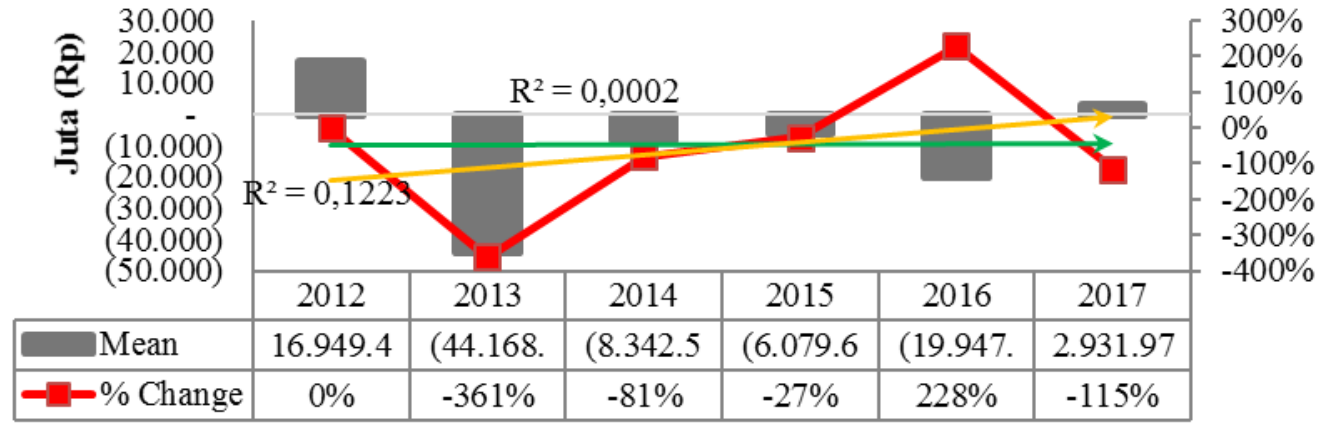

Grafik 5. Penjualan periode 2012 - 2017

Sumber: data diolah

Penurunan penjualan pada peride 2013-2016 disebabkan oleh penurunan harga jual ratarata CPO dan penurunan volume penjualan selama periode tersebut karena produksi TBS siklus rendah. Rendahnya HPP dan volume penjualan CPO, biaya bunga yang lebih tinggi, pasar lebih rendah dan peningkatan kerugian valuta asing sebagai akibat dari melemahnya IDR. Peningkatan beban bunga terutama disebabkan pinjaman yang lebih tinggi dan lebih banyak kepentingan dibebankan bukan dikapitalisasi lebih banyak ke pohon matang. Pada tahun 2013 volume penjualan hanya meningkat sedikit $0,3 \%$ dari 330 380MT menjadi 331 235MT. Pada tahun 2014 volume penjualan meningkat sedikit 36\% dari 331 235MT menjadi 210-657MT. Pada tahun 2015 volume penjualan meningkat sedikit 7\% dari 210 657MT menjadi 226 915MT. Pada tahun 2016 volume penjualan meningkat sedikit 6\% dari 211 508MT menjadi 198 565MT.

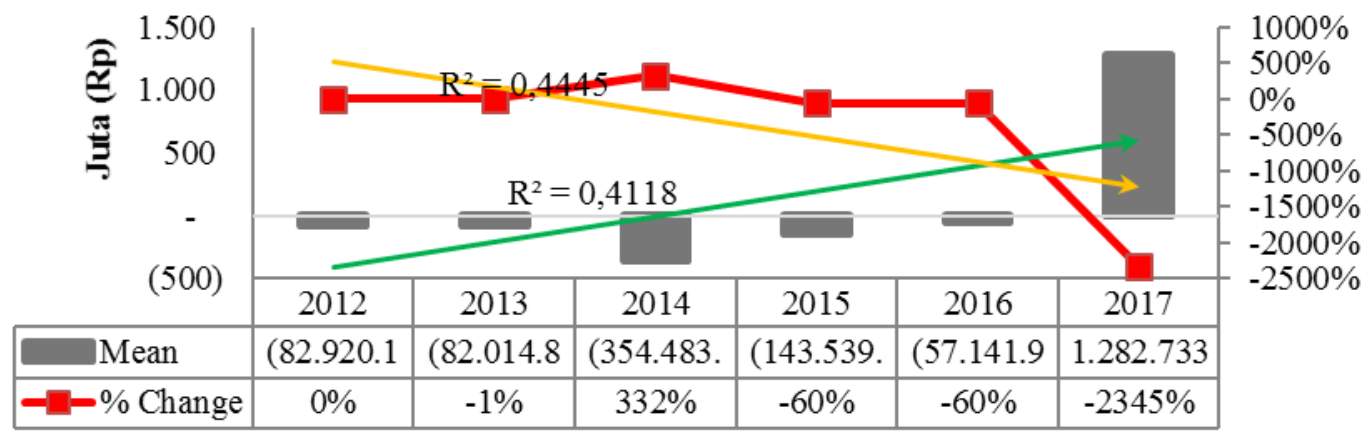

Grafik 6. Biaya Beban Umum periode 2012 - 2017

Sumber: data diolah

Penurunan trend pada persentase perubahan biaya beban umum pada periode 2012-2017 pada $\mathrm{R}$ Square 0,4445 . Sedangkan pada rata-rata biaya beban umum terjadi peningkatan trend pada R Square 0,4118. Peningkatan yang sangat signifikan terjadi pada tahun 2017 terjadi perubahan $2345 \%$ sehingga biaya beban umum rata-rata dikeluarkan sebesar Rp 1.282.733.888,disebabkan karena tidak adanya beberapa biaya refinancing bank dan biaya restrukturisasi yang terjadi pada tahun 2016.

\section{Faktor-faktor Kinerja Utilisasi ERP, ERP dan SCA terhadap Kinerja Perusahaan}

Apabila terdapat indikator yang memiliki nilai loading factor $<0,5$, harus dilakukan perhitungan kembali terhadap model awal sehingga menghasilkan loading factor seluruh indikator reflektif bernilai > 0,5 sebagai kriteria dari uji validitas convergent konstruk laten (Ghozali 2008). Gambar 2 menunjukkan terdapat indikator yang memiliki nilai loading factor < 0,5 sehingga perlu dilakukan perhitungan kembali terhadap model. Setelah dilakukan beberapa perhitungan, diperoleh model SEM akhir pada Gambar 3 menunjukkan semua indikator telah memiliki loading factor $>0,5$.

Jurnal Manajemen dan Organisasi (JMO)

Vol. 9, No. 1, April 2018, Hal. 22-34 
Jurnal Manajemen dan Organisasi (JMO),

Vol. 9, No. 1, April 2018, Hal. 22-34

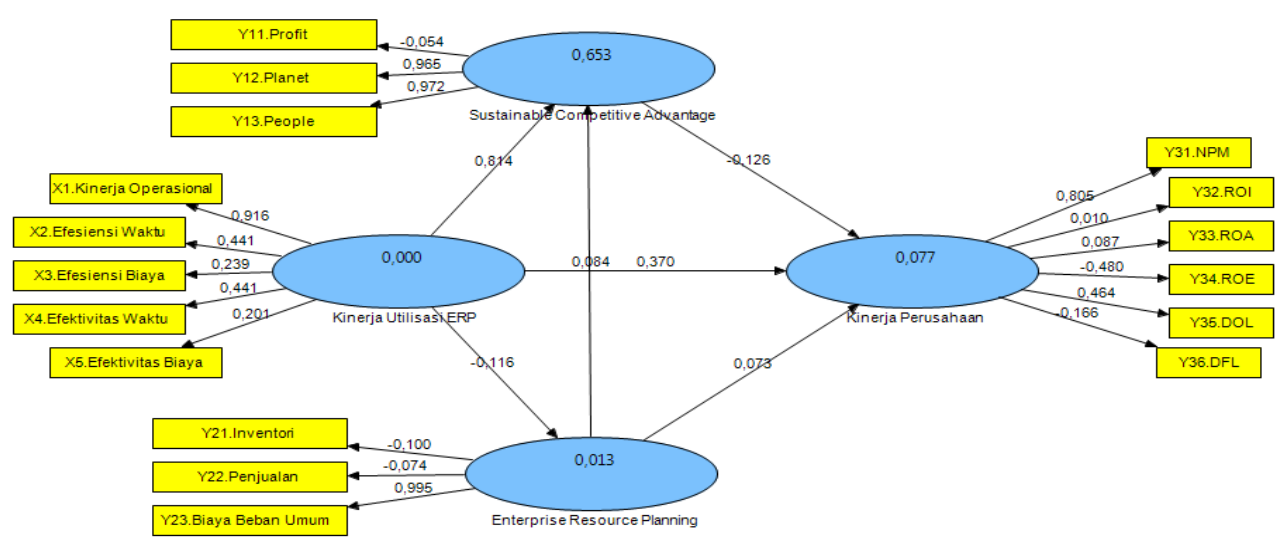

Gambar 2. Loading factor pada model pengukuran awal Sumber: data diolah

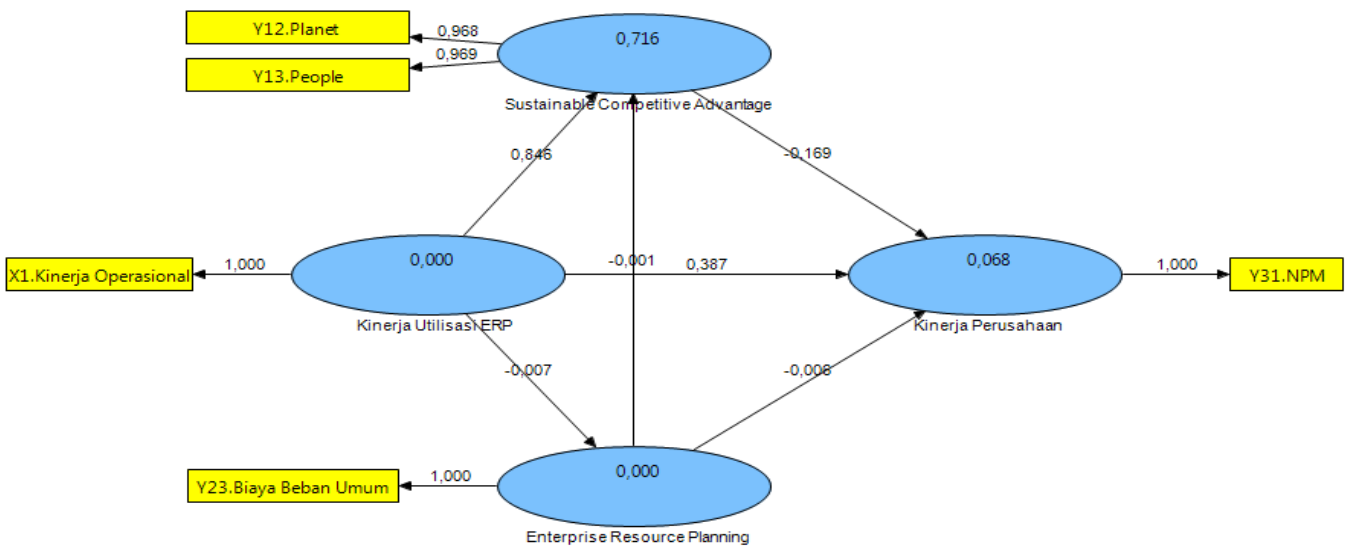

Sumber: data diolah

Gambar 3. Loading factor pada model pengukuran akhir

Syarat model memiliki validitas yang baik apabila masing-masing variabel laten dengan indikator reflektif memiliki AVE > 0,5. Hasil analisis yang terlihat pada Tabel 1, nilai AVE dari masing-masing variabel laten memiliki nilai > 0,5 dan dapat dikatakan bahwa model PLS memenuhi syarat validitas convergent yang baik.

Tabel 1. Nilai average variance extraxted (AVE), composite reliability dan cronbach alpha

\begin{tabular}{lcc}
\hline & AVE & Composite Reliability \\
\hline Enterprise Resource Planning & 1,00 & 1,00 \\
Kinerja Perusahaan & 1,00 & 1,00 \\
Kinerja Utilisasi ERP & 1,00 & 1,00 \\
Sustainable Competitive Advantage & 0,94 & 0,97 \\
\hline
\end{tabular}

Sumber: data diolah

Pengukuran selanjutnya yaitu pengujian reliabilitas terhadap model yang digunakan untuk membuktikan keakuratan, konsistensi, dan ketepatan instrumen dalam mengukur konstruk. Uji reliabilitas dengan mengukur composite reliability terhadap variabel laten yang memiliki nilai > 0,7 dikatakan reliabel. Hasil penelitian berdasarkan Tabel 1, menunjukkan semua konstruk laten memiliki reliabilitas yang baik, akurat dan konsisten karena memenuhi syarat dengan nilai composite reliability pada setiap konstruk laten lebih dari 0,7 .

Pengujian validitas discriminant dilakukan dengan prinsip bahwa pengukur-pengukur (manifest variabel) konstruk yang berbeda seharusnya tidak berkolerasi tinggi (Ghozali 2008). Tabel 2 menunjukkan bahwa nilai korelasi antar konstruk secara keseluruhan telah kurang dari nilai $\sqrt{ }$ AVE dapat dikatakan bahwa model telah memenuhi syarat validitas discriminant. 
Tabel 2. Matriks nilai korelasi dan $\sqrt{ }$ AVE antara variabel

\begin{tabular}{|c|c|c|c|c|}
\hline & $\begin{array}{c}\text { Enterprise } \\
\text { Resource } \\
\text { Planning }\end{array}$ & $\begin{array}{c}\text { Kinerja } \\
\text { Perusahaan }\end{array}$ & $\begin{array}{c}\text { Kinerja } \\
\text { Utilisasi } \\
\text { ERP }\end{array}$ & $\begin{array}{c}\text { Sustainable } \\
\text { Competitive } \\
\text { Advantage }\end{array}$ \\
\hline Enterprise Resource Planning & $\sqrt{\mathrm{AVE}}=1,00$ & & & \\
\hline Kinerja Perusahaan & $-0,01$ & $\sqrt{ } \mathrm{AVE}=1,00$ & & \\
\hline Kinerja Utilisasi ERP & $-0,01$ & 0,24 & $\sqrt{\mathrm{AVE}}=1,00$ & \\
\hline Sustainable Competitive Advantage & $-0,01$ & 0,16 & 0,85 & $\sqrt{ } \mathrm{AVE}=0,97$ \\
\hline
\end{tabular}

Sumber: data diolah

\section{Evaluasi Model Struktural}

Hasil bootstrapping pada Tabel 3 menunjukkan Kinerja Utilisasi ERP memiliki pengaruh yang signifikan terhadap SCA pada taraf $1 \%$ karena nilai t-statistik 5,15 > t-tabel $(2,59)$. Kinerja Utilisasi ERP juga memiliki pengaruh yang signifikan terhadap Kinerja Perusahaan pada taraf $1 \%$ karena nilai t-statistik 4,95 > t-tabel $(2,59)$. Selain itu, SCA juga berpengaruh signifikan terhadap Kinerja Perusahaan pada taraf $10 \%$ karena nilai t-Statistik 1,71 > t-tabel $(1,65)$.

Tabel 3. Nilai Path coefficient dan t-statistik

\begin{tabular}{lccc}
\hline & $\begin{array}{c}\text { Path } \\
\text { coefficient }\end{array}$ & $\begin{array}{c}\text { T- } \\
\text { statistik }\end{array}$ & R-square \\
\hline Kinerja Utilisasi ERP -> Sustainable Competitive Advantage & 0,846 & $52,15^{* * * *}$ & 0,716 \\
Enterprise Resource Planning -> Sustainable Competitive & $-0,001$ & $0,07^{* * *}$ & \\
Advantage & $-0,007$ & $0,27^{* * *}$ & 0,000 \\
Kinerja Utilisasi ERP -> Enterprise Resource Planning & 0,387 & $4,95^{* * *}$ & 0,068 \\
Kinerja Utilisasi ERP -> Kinerja Perusahaan & $-0,169$ & $1,71^{* * *}$ & \\
Sustainable Competitive Advantage -> Kinerja Perusahaan & $-0,006$ & $0,40^{* * *}$ & \\
Enterprise Resource Planning -> Kinerja Perusahaan & & \\
Keterangan: ***) pengaruh signifikan pada taraf 1\% (T-statistik > T-tabel (2,59)); **) pengaruh signifikan pada taraf \\
5\% (T-statistik > T-tabel (1,97)); *)pengaruh signifikan pada taraf 10\% (T-statistik > T-tabel $(1,65))$ \\
Sumber: data diolah
\end{tabular}

Kinerja Utilisasi ERP memiliki pengaruh terhadap SCA sebesar 0,846 artinya semakin meningkat Kinerja Utilisasi ERP yang diukur melalui Kinerja Operasional yang tinggi maka akan semakin meningkatkan SCA yang diukur melalui People dan Planet yang semakin tinggi. Selain itu, Kinerja Utilisasi ERP juga memiliki pengaruh terhadap Kinerja Perusahaan sebesar 0,387 artinya semakin meningkat Kinerja Utilisasi ERP yang diukur melalui Kinerja Operasional yang tinggi maka akan semakin meningkatkan Kinerja Perusahaan yang diukur melalui NPM yang semakin meningkat. Sedangkan SCA memiliki pengaruh terhadap Kinerja Perusahaan sebesar -0,169 artinya semakin meningkat SCA yang diukur melalui Planet dan People yang tinggi maka akan semakin menurunkan Kinerja Perusahaan yang diukur melalui NPM. Model struktural SCA menghasilkan nilai R-square 71,6\% artinya keragaman SCA yang mampu dijelaskan oleh model sebesar 71,6\% sedangkan sisanya $28,4 \%$ dijelaskan oleh faktor lain diluar model. Model struktural Kinerja Perusahaan menghasilkan nilai R-square 6,8\% artinya keragaman Kinerja Perusahaan yang mampu dijelaskan oleh model sebesar 6,8\% sedangkan sisanya 93,2\% dijelaskan oleh faktor lain diluar model.

Hasil uji signifikan berdasarkan kinerja utilisasi ERP berpengaruh positif terhadap kinerja perusahaan (hipotesis 1) diukur dengan kinerja operasional yang meningkat maka akan meningkatkan Net Profit Margin pada taraf 1\% dengan nilai 0,387 (Tabel 3). Begitu juga hasil uji signifikan berdasarkan kinerja utilisasi ERP berpengaruh positif terhadap sustainable competitive advantage (hipotesis 2) diukur dengan kinerja operasional yang meningkat maka akan mengefektifitaskan luasan areal tanam kebun (planet) dan jumlah pekerja di kebun tersebut (people) berdasarkan norma-norma kebutuhan pekerja pada luasan areal kebun pada taraf $1 \%$ dengan nilai 0.846 (Tabel 3). Hasil uji tidak signifikan berdasarkan pengaruh kinerja utilisasi ERP terhadap enterprice resource planning (hipotesis 3). Demikian juga dengan pengaruh sustainable competitive advantage terhadap kinerja perusahaan (hipotesis 4) pengaruh

Jurnal Manajemen dan Organisasi (JMO),

Vol. 9, No. 1, April 2018, Hal. 22-34 
enterprice resource planning terhadap kinerja perusahaan (hipotesis 5) Hasil uji tidak signifikan berdasarkan pengaruh enterprice resource planning terhadap sustainable competitive advantage (hipotesis 6) (Tabel 3).

Dengan hasil analisis dan prediksi metode SEM pada penelitian ini disimpulkan dari faktor-faktor variabel penelitian ini hanya satu faktor setiap variabel laten yang diteliti yang berpengaruh yaitu: Variabel Kinerja Utilisasi ERP faktor yang berpengaruh adalah kinerja operasional, variabel Enterprise Resource Planning faktor yang berpengaruh adalah biaya beban umum, variabel Sustainable Competitive Advantage faktor yang berpengaruh adalah Planet dan People, variabel kinerja perusahaan faktor yang berpengaruh adalah Net Profit Margin. Dari hasil analisis prediksi SEM, penelitian ini melakukan pengujian pada analisis Regresi.

Tabel 4 Hasil Perhitungan Regresi

\begin{tabular}{lr}
\hline \multicolumn{2}{c}{ Regression Statistics } \\
\hline Multiple $R$ & 0,27 \\
$R$ Square & 0,08 \\
Adjusted R Square & 0,06 \\
Standard Error & 14,80 \\
Observations & 360,00 \\
\hline
\end{tabular}

\begin{tabular}{lccccc} 
ANOVA & \multicolumn{7}{c}{ SS } & $M S$ & $F$ & Significance $F$ \\
\hline Regression & $4 f, 00$ & $6.326,81$ & $1.581,70$ & 7,22 & 0,00001347 \\
Residual & 355,00 & $77.791,86$ & 219,13 & & \\
Total & 359,00 & $84.118,66$ & & & \\
\hline
\end{tabular}

Jurnal Manajemen dan Organisasi (JMO), Vol. 9, No. 1, April 2018, Hal. 22-34

\begin{tabular}{lcccccccc}
\hline & Coefficients & $\begin{array}{c}\text { Standard } \\
\text { Error }\end{array}$ & t Stat & P-value & $\begin{array}{c}\text { Lower } \\
95 \%\end{array}$ & $\begin{array}{c}\text { Upper } \\
95 \%\end{array}$ & $\begin{array}{c}\text { Lower } \\
95,0 \%\end{array}$ & $\begin{array}{c}\text { Upper } \\
95,0 \%\end{array}$ \\
\hline Intercept & $(7,2620914)$ & 1,852336 & $(3,9205)$ & 0,00011 & $(10,91)$ & $(3,62)$ & $(10,91)$ & $(3,62)$ \\
X1.Kinerja & 0,0000000 & 0,000000 & 4,1451 & 0,00004 & 0,00 & 0,00 & 0,00 & 0,00 \\
$\begin{array}{l}\text { Operasional } \\
\text { X2.Planet }\end{array}$ & 0,0005878 & 0,000768 & 0,7650 & 0,44477 & $(0,00)$ & 0,00 & $(0,00)$ & 0,00 \\
$\begin{array}{l}\text { X3.People } \\
\text { X4.Biaya }\end{array}$ & $(0,0121352)$ & 0,005280 & $(2,2983)$ & 0,02213 & $(0,02)$ & $(0,00)$ & $(0,02)$ & $(0,00)$ \\
$\begin{array}{l}\text { Beban } \\
\text { Umum }\end{array}$ & $(0,0000000)$ & 0,000000 & $(0,3414)$ & 0,73298 & $(0,00)$ & 0,00 & $(0,00)$ & 0,00 \\
\hline
\end{tabular}

Sumber: data diolah

Berdasarkan hasil analisis regresi pada Tabel 4 menghasilkan nilai $R$ Square sebesar $8 \%$. Hasil tersebut menunjukkan bahwa variasi variabel independen yang digunakan dalam model mampu menjelaskan sebesar $8 \%$ variasi variabel dependen, sementara sisanya sebesar $92 \%$ dipengaruhi oleh variabel lain yang tidak dimasukkan dalam penelitian ini.

Berdasarkan model regresi yang dihasilkan dapat diketahui bahwa untuk mencapai kinerja perusahaan maka indikator yang paling berpengaruh yaitu planet dan biaya beban umum. Hasil analisis menunjukkan bahwa planet dan biaya beban umum memiliki nilai signifikan kurang dari 0,05 , maka untuk semua variabel tersebut berpengaruh nyata terhadap kinerja perusahaan, sedangkan variabel lainnya tidak berpengaruh nyata. Hasil yang didapat dari analisis regresi linear berganda menyatakan bahwa enterprise resource planning dan sustainable competitive advantage berpengaruh terhadap kinerja perusahaan. Hal ini berarti dalam membuat suatu keputusan investasi pada implementasi ERP berdasarkan 2 periode 2015 
sampai 2017 belum optimal, diharapkan perusahaan dapat berkompetisi secara berkelanjutan yang bertujuan meningkatkan kinerja perusahaan.

\section{KESIMPULAN}

Berdasarkan hasil analisa data dan pembahasan yang telah dikemukakan maka dapat ditarik kesimpulan:

1. Secara keseluruhan kinerja utilisasi ERP di perusahaan kinerja operasional, efesiensi waktu dan efektifitas waktu dari faktor-faktor yang diteliti pada tahun ke2 setelah implementasi ERP memberikan hasil positif dari sisi informasi kinerja operasional perusahaan.

2. Implementasi ERP menurunkan biaya beban umum namun tidak menurunkan Inventory. Peningkatan Penjualan tidak terlihat pada tahun 2016-2017.

3. Faktor-faktor ERP dan SCA yang mempengaruhi kinerja perusahaan adalah Kinerja Utilisasi ERP (Kinerja Operasional) yang tinggi maka akan mengefektifitaskan luasan areal tanam kebun (planet) dan jumlah pekerja di kebun tersebut (people) berdasarkan normanorma kebutuhan pekerja pada luasan areal kebun pada taraf $1 \%$ dengan nilai 0,846 . Selain itu, semakin meningkat Kinerja Utilisasi ERP yang tinggi maka akan semakin meningkatkan Kinerja Perusahaan yang semakin meningkat pada taraf $1 \%$ dengan nilai 0,387. Semakin meningkat SCA (Planet dan People) maka tidak signifikan meningkatkan net profit margin pada taraf $10 \%$ dengan nilai $-0,169$.

4. Adanya pengaruh signifikan dari faktor-faktor kinerja utilisasi ERP yang dapat mempengaruhi kinerja perusahaan dari hasil perhitungan SEM (hipotesis 1) diukur dengan kinerja operasional yang meningkat maka akan meningkatkan Net Profit Margin pada taraf $1 \%$ dengan nilai 0,387 . Sedangkan dari hasil perhitungan regresi bahwa enterprise resource planning dan sustainable competitive advantage berpengaruh terhadap kinerja perusahaan dengan faktor biaya beban umum dan planet memiliki nilai signifikan kurang dari 0,05. Dampak ERP terhadap kinerja perusahaan yang dilihat oleh perusahaan ini terjadi penurunan biaya beban umum seperti paperless. Sementara dampak SCA terhadap kinerja perusahaan yang dilihat kondisi perusahaan saat ini adalah Planet seperti luasan areal masih belum mencapai satuan hektar per pokok dan People seperti standar jumlah tenaga kerja belum sesuai dengan normatif luasan kebun.

\section{DAFTAR PUSTAKA}

Aladwani. 2001. Change management strategies for successful ERP implementation. Business Process Management Journal, Vol. 7 No. 3 , 266-275.

Albert H. Segars and Varun Grover. 1998. Strategic Information Systems Planning Success: An Investigation of The Construct and Its Measurement. MIS Quarterly Vol 22 No 2 , 139163

Ben Light, Christopher P. Holland, dan Karl Wills. 2001. ERP and Best of Breed: A Comparative Analysis. Business Process Management Journal Vol. 7 No. 3 , 1463-7154.

Brandit R. Allen and Andrew C. Boynton. 1991. Information Architecture: In Search of Effecient Flexibility. MIS Quarterly Vol 15 No 4 , 435-445.

Dale L.Goodhue; Judith A. Quillard; John F. Rockart. 1988. Managing the Data Resource: A Contingency Perspective. MIS Quarterly Vol 12 No 3 , 373-392.

Edward Bernroider dan Stefan Koch. 2001. ERP selection process in midsize and large organizations. Business Process Management Journal, Vol. 7 No. 3 , 251-257.

Elkington, J. 1998. Cannibals with forks: the triple bottom line of 21st century business. New Society Publishers.

Erik Brynjolfsson and Lorin M.Hitt. 1998. Beyond The Productivity Paradox. The Business Value of IT , 49-55 
Fiona Fui - Hoon Nah; Janet Lee - Shang Lau and Jinghua Kuang. 2001. Critical factors for successful implementation of enterprise systems. Business Process Management Journal, Vol. 7 No. 3, , 285-296.

Francisco J. Mata, William L. Fuerst, Jay B. Barney. 1995. Information Technologi and Sustained Competitive Advantage: A Resource-Based Analysis. MIS Quarterly , 487505 .

Ghozali. 2008. Structural Equation Model Metode Alternatif Dengan Partial Least Square (PLS). Semarang: Ed Ke2 Universitas Diponegoro.

GS Kearns dan AL Lederer. 2000. Pengaruh Penyelarasan Strategis tentang Penggunaan Sumber Daya berbasis IS untuk Keunggulan Kompetitif. Journal of Strategic Information Systems 9, 265-293.

H. Russell Johnston and Michael R. Vitale. 1988. Creating Competitive Advantage with Interorganizational Information System. MIS Quarterly Vol 12 No 2 , 153-165.

Hsu, P.-F. 2013. Integrating ERP and e-business: Resource complementarity in business value creation . Decision Support Systems , 334-347.

Hunton, J. E. 2003. Enterprice Resource Planning System: Compaaring Firm Performance of Adapter and nonadapter. International Journal of Accounting Information System , 165184.

L.Goodhue, D., Quillard, J. A., \& Rockart, J. F. 1988. Managing the Data Resource-A Contingency Perspective. MIS Quarterly, 373-392.

Marinos Themistocleous, Zahir Irani dan Robert M. O'Keefe. 2001. ERP and Application integration. Business Process Management Jurnal Vol 7 no 3 , 1463-7154.

Paul Hawking, Adrian Ramp dan Peter Shackleton. 2001. IS'97 model curriculum and enterprise resource planning systems. Business Process Management Journal, Vol. 7 No. 3, , 225233.

Rodney McAdam and Daniel McCormack. 2001. Integrating business processes for global alignment and supply chain managemen. Business Process Management Journal, Vol. 7 No. $2,113-130$.

Ruivo, P. 2014. Examine ERP post-implementation stages of use and value: Empirical evidence from Portuguese SMEs . International Journal of Accounting Information Systems , 166184.

Subba Rao Siriginidi. 2000. Enterprice Resource Planning in Reengineering Business. Business Proses Management, 1463-7154.

Sujarweni, V. 2014. Metode Penelitian. Yogyakarta: Pustaka Baru Pers.

Susan Clemmons, Steven John Simon. 2001. Control and coordination in global ERP configuration. Business Process Management Journal, Vol. 7 No. 3 , 205-215.

Jurnal Manajemen dan Organisasi (JMO), Vol. 9, No. 1, April 2018, Hal. 22-34
Umar, H. 2013. Metode Penelitian untuk Skripsi dan Tesis Bisnis. Jakarta: Gramedia Pustaka Utama.

Zhenyu Huang dan Prashant Palvia. 2001. ERP implementation issues in advanced and developing countries. Business Process Management Journal, Vol. 7 No. 3, , 1463-7154. 